\author{
Anna Kyrychenko \\ Assistant of the Department of Economics \\ of the National Transport University, Kyiv, Ukraine, \\ e-mail:anna_dazenko@ukr.net \\ https://orcid.org/0000-0002-3783-0804
}

\title{
THE ESSENCE OF THE CONCEPT OF MANAGEMENT ON THE BASIS OF VALUE AND METHODICAL APPROACHES TO ITS TAKING INTO ACCOUNT IN FORMING THE STRATEGY OF ROAD TRANSPORT ENTERPRISE DEVELOPMENT
}

\begin{abstract}
The key objectives of the value-based management concept are to maximize the market value of the enterprise. The article considers the essence of this concept, analyzes the research of domestic and foreign scientists, the factors that create value. It is determined that for a development-oriented enterprise, the formation of a flexible and far-sighted strategy focused on increasing the value of the enterprise is important, especially given the cyclical dynamics of the national and global economy, the high probability of financial, economic, social, political crisis and / or pandemic, increasing conditions of uncertainty and risk.

The stages of realization of the concept of value management which have found the practical application at the road transport enterprises are proved. It is proved that the formation of a development strategy using a value approach for these enterprises requires adaptation to domestic realities. In turn, attractive, in terms of value, road transport companies have ample opportunities to attract external financial resources needed for further development, as well as a high level of competitiveness and significant economic potential.

Keywords: VBM, value-based management, enterprise value, market value maximization, value concept, development strategy, road transport, road transport enterprises.
\end{abstract}

Formulation of the problem. Researches on modern issues of value management is increasing due to the dynamics of technological change, high levels of market activity, the need to quickly adapt to instability and respond adequately to crises, new challenges, growing risks. For a development-oriented enterprise, the formation of a flexible and far-sighted strategy becomes extremely important, especially given the cyclical dynamics of the national and global economy, the high probability of financial, economic, social, political crisis and / or pandemic, increasing uncertainty and risk. The development of road transport enterprises is in the interests of many stakeholders, from owners, managers, employees, consumers, government officials and local governments to representatives of all other economic actors and the civil society. Therefore, the study of theoretical, methodological and applied issues of development strategy based 
on the concept of value-based management is relevant not only at the level of individual carriers and other economic entities, but also in creating additional conditions for stable functioning of the national socio-economic system in general.

Analysis of recent research and publications. Some issues of the concept of management based on value, the process of forming a strategy for the development of road transport enterprises were part of the scientific works of both domestic and foreign scientists, namely: M.N. Bednyak, V.V. Bilichenko, K.L. Zheleznyak, O.V. Klepikova, O.P. Levchenko, H.V. Mitchenko, Yu. A. Palamarchuk, Ye.V. Smirnova, I.V. Shevchenko, V.H. Shinkarenko, S.V. Tsymbal, O. Zamaziy, O. Mendrul, V. Bazylevych, T. Tomalya, H. Yanchuk, I. Plikus, I. Yaremko, V. Shypov, P. Drucker, G. Ostrovska, A. Rappoport, D. Walters, E. Black, F. Wright, J. Bachman, R. Miles [1-15] and others. The researches are based mostly on foreign experience without proper adaptation to modern realities. Today, the methodological and organizational aspects of the concept of strategic management based on value, in particular in transport enterprises, are not properly disclosed, and existing scientific developments have not been brought to the level of practical application.

Purpose of the article: study of theoretical bases and essence of the concept of management on the basis of value, use of methodical approaches at formation of strategy of development of the enterprises of road transport and substantiation of necessity and efficiency of application of the concept VBM - Value Based Management in practice.

Presentation of main material. Value Based Management (VBM) is a concept that implies the need to define the goals of business-operations, as well as the integration of the goals of the managers and business owners. The VBM focuses on the need to obtain maximum value for all the stakeholders, which is why it is considered universal. It is also the link that combines the company's strategy with the financial results.

Thus, value management is a philosophy of enterprise management according to which management activities and processes are focused on maximizing the value in terms of the interests of the owners of borrowed capital. According to the concept of the VBM the increase in value is the main goal of the enterprise, and all the efforts of the managers should be aimed not so much at increasing profits as at increasing the market value of the enterprise.

This concept involves the adoption of strategic, operational and investment decisions of the enterprise, which will help achieve the main goal - to increase its value. According to the value concept of management, the quantitative interpretation of the capabilities (potential) of the enterprise is its value [7]. Enterprise value management is the relationship between the strategy and the financial results of an enterprise. Therefore it is impossible to speak about effective management excluding one of these categories. A rational solution is the appropriate formulation of the company's strategy the management of which is focused on achieving the best financial results.

The financial effects of value maximization strategies are usually described by the relationship between the growth rates, the generated cash flows and the return on equity. Accounting profit can not be a criterion for assessing the effectiveness of the activities, and also can not be an indicator of achieving the goal of the enterprise maximizing the value $[11,338]$.

The long-term goal of the company is not the accounting profit, but the value of 
the company. In contrast to profits, the increase in value is beneficial for all groups of stakeholders associated with the enterprise. The company cannot increase the value at the expense of employees, customers or suppliers. The greater the turnover of staff, the more difficult it will be to create additional value. Nor should customers who have a wide choice of goods and services in the market economy be underestimated. The situation is similar with suppliers. The failure to fulfill their obligations to them may result in their loss. Therefore, there is no objective possibility of enrichment of the owners at the expense of employees or other groups around the company [13].

Increasing the value of the enterprise also creates additional value for the society [10]. Only the management focused on increasing the value of the enterprise makes better decisions and aims to reach compromises regardless of the social conditions in which the enterprise operates [4]. The value of the enterprise is a specific, pragmatic, future-oriented goal that motivates the management to constantly improve its development strategy.

Domestic researchers believe that: the value of the enterprise is the most important indicator of the efficiency of the enterprise, the only criterion for assessing the financial well-being (O. Zamaziy [3], O. Mendrul [5], T. Tomalya, H. Yanchuk); the sum of the values of the elements that make up the enterprise (I. Yaremko [9]). V. Shypov gave a detailed description of the value of the enterprise: it is the probabilistic monetary value that a potential buyer will be willing to pay for the enterprise, i.e. simultaneously for all its assets, as a result of a commercial agreement between the seller and the buyer.

A person (individual / legal entity) who wants to buy a company is interested not only in how it has managed so far, but also, first of all, whether it will bring real benefits in the future. Therefore, the buyer pays attention mainly to the development potential and competitive advantage, current or potential.

A necessary condition for the effective functioning of each enterprise are the stakeholders [1]. Enterprises change along with economic development. The new reality requires the management of enterprises to change the principles of their operation. For the effective implementation of the concept of value management VBM, as well as for its further effective use, it is necessary to know the mechanisms and tools for assessing the consequences of activities using this concept. It is also necessary to implement an effective and proactive system of corporate management, which would create a mechanism that integrates the goals of the managers with the goals of the owners and other stakeholders.

The value management strategy of the enterprise, as well as the evaluation process, combines two main areas of financial decisions: business financing and investment, i.e. efficient use of the capital. To achieve greater value of the enterprise it is necessary to look for more economical sources of financing, and the growth obtained in this way should be aimed at effective investment. The goal of value maximization means the need to maximize the capital while generating the maximum possible cash flow. Value management requires the company to introduce criteria that evaluate the effectiveness of the decisions, as well as to identify all the factors that may affect the increase in value. In addition, it is necessary to use special methods to assess the methods and rates of value formation.

According to H. Ostrovska, the value management system is based on identifying and optimizing the key value factors that are important for two reasons: firstly, the 
company can not work directly with the value, and secondly, these actual value factors help senior managers to understand what is happening at all other levels of the company, and communicate to them their intentions [6].

One of the main tasks of the company's management that seeks to maximize the value of the shareholders should be to determine the factors that create the value of the enterprise. In scientific researches you can find different views on the classification of sources of enterprise value.

A. Rappoport was one of the first to identify the factors that shape the value of the enterprise; among the main components he singled out: cash flow from operational activities; discount rate; obligations. Later the scientist identified seven main factors that shape the value [15]: the period of value increase, sales growth rate, operating profit margin, investment in fixed assets, working capital investment, income tax rate, value of the capital.

D. Walters, in addition to the factors mentioned by Rappoport, notes that the value is affected by: customer loyalty management, ,joint production', i.e. the inclusion of suppliers and customers in the value creation process, operating leverage, financial leverage, strategic and operational cash flows, management of the available and used production facilities.

According to D. Walters, the role of these factors in the process of creating the value is great, so it is correct to define them as the basis of the value management. Walters divides these value factors into: operational and strategic. Operational factors include those that operations managers can manage by implementing the company's value creation strategy. E. Black, F. Wright and J. Bachman divide the factors of value creation into: strategic, financial and operational. Strategic factors include: risk, profitability and growth. Financial factors are those presented by A. Rappoport. Operational factors are not universal, they are specific to each individual enterprise and should be defined so that they can be used at the lowest organizational level [10]. The authors also presented a wide group of factors that are not reflected in the accounting standards (Fig. 1).

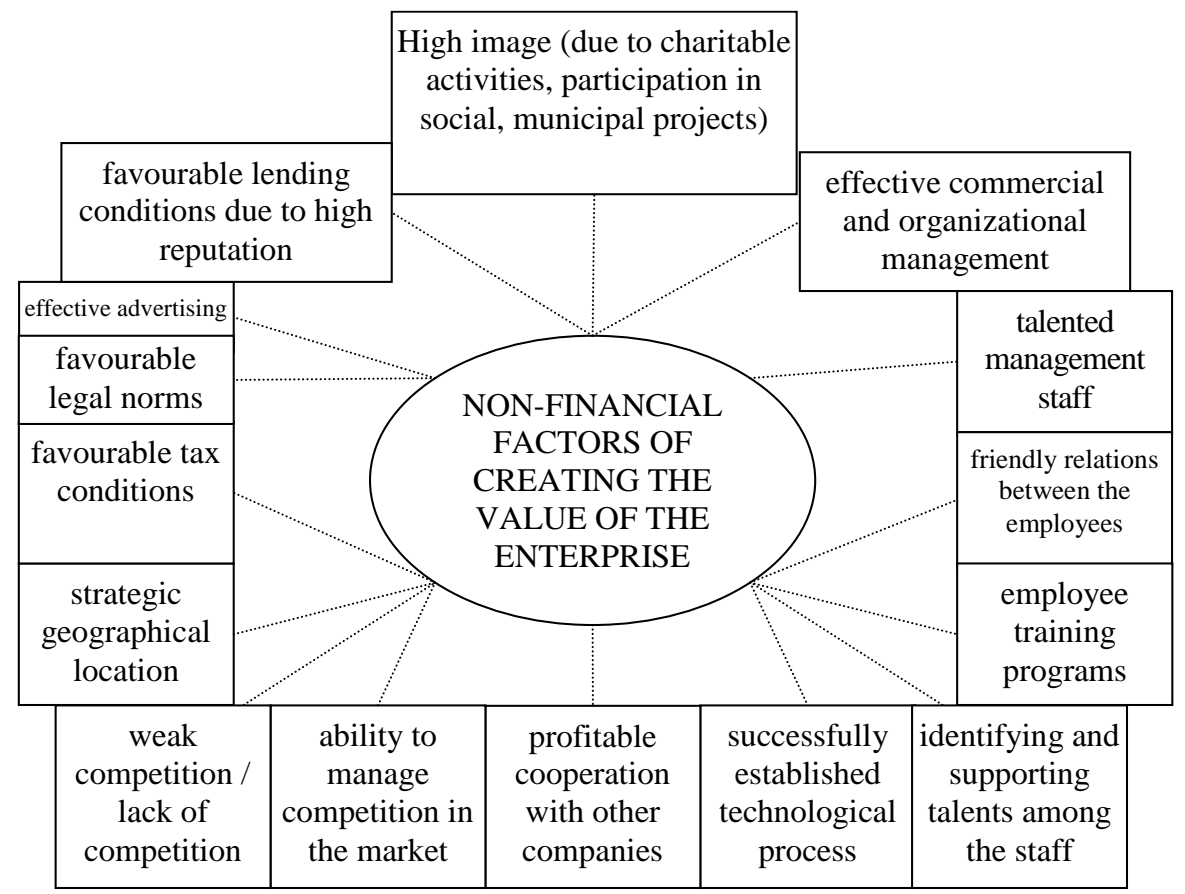

Fig. 1. Non-financial factors of the value creation of the enterprise Source: grouped by the author [10] 
Therefore, the factors that create the value can be divided into two groups:

1) factors related to the components of the balance sheet - elements that are included / should be included in the company's balance sheet or related to the indicators of assets and liabilities,

2) factors not related to the components of the balance sheet are data that are not included in the official balance sheet. This group of factors clearly distinguishes between the external, upon which the company has limited or no influence, and the internal, which directly depend on the company and can be formed by it.

In general, all sources of value can be divided into those that depend on the enterprise and independent, but create value / influence its creation.

The many different factors that create the value of an enterprise mean that there is no single universal way to ensure maximum value for different enterprises. But the effectiveness of the concept of enterprise management VBM depends not only on identifying all the factors and processes that shape the value, but also on determining their goals, formulating the strategy and establishing the appropriate system of control over the projects being implemented. The main conditions for the successful implementation of VBM include [14]:

- full support from the management of the enterprise;

- making appropriate decisions by the operational staff;

- tight integration of the VBM with all the elements of planning and management;

- reducing the importance of methodology, focusing on practical aspects;

- ensuring free access to information (balance sheets, results of external benchmarks);

- providing standardized and easy-to-use valuation templates and report templates to facilitate operations;

- connection of the motivational system with the value strategy, all human resources must be evaluated in terms of their impact on the value of the enterprise.

If the necessary conditions exist at the given enterprise, it is possible to realize separate stages of implementation of the concept of management of value. Value management is one of the forms of strategic management, therefore, it is a combination of four main management processes that should be considered when implementing this system (Table 1).

Table 1. Stages of implementation of the concept of value management

\begin{tabular}{|c|l|}
\hline $\begin{array}{c}\text { Stages of the } \\
\text { management process }\end{array}$ & Content \\
\hline & Stage I \\
\hline $\begin{array}{c}\text { Setting specific } \\
\text { goals }\end{array}$ & $\begin{array}{l}\text { Identification of goals. Formation of a 'beam of goals'. } \\
\text { Hierarchy of goals. Goals should be based on the factors that } \\
\text { bring the company the greatest added value, providing the main } \\
\text { goal - to maximize profits and subordinate it to the goals of the } \\
\text { lower level. Goals should bring financial benefits to the owners, } \\
\text { as well as meet the expectations of other stakeholders. Goals } \\
\text { should reflect the aspirations of the enterprise, taking into } \\
\text { account the real possibilities of achieving them }\end{array}$ \\
\hline
\end{tabular}




\begin{tabular}{|c|c|}
\hline \multicolumn{2}{|r|}{ Stage II } \\
\hline $\begin{array}{c}\text { Strategy } \\
\text { development }\end{array}$ & $\begin{array}{l}\text { Strategy - a way to implement and achieve goals, should } \\
\text { promote the formation of competitive advantage that will } \\
\text { allow the company to achieve additional benefits for the } \\
\text { shareholders. Also important for creating the value are } \\
\text { increasing the volume of activity, the scale of operations, } \\
\text { reducing costs and improving product quality }\end{array}$ \\
\hline & Stage III \\
\hline $\begin{array}{l}\text { Development and } \\
\text { adoption of action } \\
\text { plans and } \\
\text { preparation of } \\
\text { relevant budgets }\end{array}$ & $\begin{array}{l}\text { Action plans and relevant budgets translate the strategy into } \\
\text { current and future operational decisions, they also allow you } \\
\text { to control the management of the company and its employees } \\
\text { in terms of implementation of the plans and compliance with } \\
\text { the budgets }\end{array}$ \\
\hline & Stage IV \\
\hline $\begin{array}{l}\text { Creation and } \\
\text { implementation of } \\
\text { performance } \\
\text { evaluation systems / } \\
\text { value maximization }\end{array}$ & $\begin{array}{l}\text { Evaluation systems are needed when transforming strategy } \\
\text { into data measurement. They help evaluate the achievements, } \\
\text { focus on maximizing the value for the owners. Within the } \\
\text { framework of different approaches it is possible to allocate: } \\
\text { indicators of financial character reflecting economic activity } \\
\text { of the enterprise; strategic indicators, i.e. those that illustrate } \\
\text { the non-financial aspects of the operations. The meters should } \\
\text { be related to value-generating factors and adapted to each } \\
\text { individual enterprise. Indicators have: } \\
\text {-reflect the economic content of the activity; } \\
\text {-be accurate and easy to understand; } \\
\text {-send sequential signals in the management; } \\
\text {-maximize the value of the business; } \\
\text {-be correlated with the benefit of the owners; } \\
\text {-promote management communication and information } \\
\text { support. }\end{array}$ \\
\hline
\end{tabular}

Source: grouped by the author [1-16]

The well-known methods of measuring the efficiency of the enterprise are useful for analysis to achieve the goal - to obtain maximum value in the short and long term. They are also used to gather the information needed for the control process. Valuation should include both financial and non-financial aspects of the enterprise, which allows you to get a complete picture and establish an effective process for implementing the strategy.

Financial and non-financial (strategic) indicators are combined into a balanced matrix, in which by assessing the four prospects of the enterprise (financial, customer, internal processes and development) short-term measures and long-term growth factors are selected.

The implementation of the VBM concept at the enterprise is based on the belief of the company's managers about the benefits of management strategy through value. It is 
important to make sure that this strategy is compatible with the basic processes of the enterprise management. An enterprise valuation should also be performed to determine the expected increase in value in the forecast. If the compliance of the strategy with the management processes does not give synergies to these categories, the focus should be on training the employees.

An important step is the joint search for opportunities to improve the activities of the enterprise, as well as the establishment of the main objectives of the operational activities. Once all the employees of the company are convinced of the benefits of the VBM, the next step in implementing this concept is to create a plan of action related to the implementation of the strategy, planning and budgeting, as well as the appointment of people responsible for these processes. The action plan also includes the evaluation of the results. The last step is the implementation of the plans in the actual activities of the enterprise, in particular by creating a new management system that affects the employee motivation. The increase in the value of the enterprise is influenced by the increase in operating the profit and cash flows, achieving high sales dynamics, finding the optimal capital structure (essentially reducing the cost of obtaining sources of funding), as well as the transition from management through functions to process management. It is also important to change the managerial thinking at all levels to one that leads to the increase in the value of the enterprise.

Value management should be provided with various tools to monitor the effectiveness of the risk management, as well as knowledge and human capital. They will help to identify violations in the implementation of the strategy, as well as to check the deviation of the actual results from the planned ones.

The concept of the VBM includes the desire to link the concept of the value for customers with the value for owners, and between these two parties can also be divided into three stages of implementation of the value management strategy: creation, maintenance and implementation of the value. The concept of value management is actively used in Europe and the USA. In Ukraine it is only gaining popularity; the number of enterprises that use it is insignificant.

When applying the concept of value management in road transport enterprises there are some difficulties with its adaptation to domestic realities. Attractive, in terms of value, the road transport company has ample opportunities to attract external financial resources needed for further development, and accordingly has a high level of competitiveness and significant economic potential.

Today, maximizing the value is increasingly becoming the main goal of road transport enterprises and contributes to significant changes in approaches to management in general, also requires the development of a system of indicators to assess the performance of the enterprise adapted to the national realities. This necessitates the analysis of value indicators on the possibility of their adaptation to the reporting of domestic road transport enterprises, the development of methodological approaches to their calculation.

Conclusions. The combination of theory and practice of finance, strategy and management in one concept leads to the fact that the VBM forms a system that covers three areas of management and analytical tools: management evaluation of the enterprise, periodic evaluation of the results (for the purpose in the form of maximum 
value) and incentive programs for the managers of road transport enterprises and their employees, who link their remuneration with the goal of increasing the value of the enterprise in this period.

\section{References:}

1. Drucker, P. (2000). Zadachi menedzhmenta v XXI veke [Management Challenges for the 21 st Century]. Moscow: Izd. Dom «Viliams» [in Russian].

2. Zhelezniak, K. L. (2012). Vybir stratehii rozvytku avtotransportnoho pidpryiemstva yak elementa frahmentarnoi haluzi [The choice of strategy for the development of motor transport enterprise as an element of the fragmentary industry]. Visnyk Natsionalnoho transportnoho universytetu - Bulletin of the National Transport University, 2(26), 147-150. Retrieved from http://irbis-nbuv.gov.ua/cgi-

bin/irbis_nbuv/cgiirbis_64.exe?C21COM=2\&I21DBN=UJRN\&P21DBN=UJRN\&IMAGE_FILE_D OWNLOAD=1\&Image_file_name=PDF/Vntu_2012_26\%282\%29_30.pdf [in Ukrainian]

3. Zamazii, O.V. (2015). Formuvannia tsinnisno-oriientovanoho upravlinnia promyslovymy pidpryiemstvamy [Formation of value-oriented management of industrial enterprises]. Extended abstract of Doctor's thesis. Khmelnytskyi: Khmel. nats. un-t [in Ukrainian].

4. Copeland, T., Koller, T., Murrin, J. (2002). Stoimost kompanii: otsenka $i$ upravlenie [Valuation: Measuring and Managing the Value of Companies]. (2nd ed.). Moscow: ZAO «OlympByznes» [in Russian].

5. Mendrul, O.H. (2003). Upravlinnia vartistiu pidpryiemstv: teoretychni ta praktychni aspekty [Entrepreneurship value management: theoretical and practical aspects]. Extended abstract of Doctor's thesis. Kyiv: Kyiv. nats. ekon. un-t [in Ukrainian].

6. Ostrovska, H. Y. (2007). Zaprovadzhennia systemy vartisno-oriientovanoho upravlinnia vertykalno-intehrovanykh pidpryiemstv [Introduction of cost-oriented management systems of vertically integrated enterprises]. Halytskyi ekonomichnyi visnyk - Galician Economic Bulletin, 2, 38-51 [in Ukrainian].

7. Plikus, I.Y. (2012). Potentsial pidpryiemstva, yoho otsinka y transformatsiia: ekonomichna ta bukhhalterska interpretatsiia [Potential of the enterprise, its estimation and transformation: economic and accounting interpretation]. Finansy Ukrainy - Finance of Ukraine, 4, 91-105 [in Ukrainian].

8. Tsymbal, S.V. (2014). Obgruntuvannia stratehii rozvytku pidpryiemstv avtomobilnoho transportu []. LXH naukova konferentsiia profesorsko-vykladatskoho skladu, aspirantiv, studentiv ta spivrobitnykiv vidokremlenykh strukturnykh pidrozdiliv Natsionalnoho transportnoho universytetu - LXH scientific conference of faculty compliance, graduate students, students and staff of well-known departments of the National Transport University: Proceedings of the articles. (S. 302). Kyiv [in Ukrainian].

9. Yaremko, I.Y. (2005). Otsinka rynkovoi vartosti pidpryiemstv: porivnialnyi pidkhid [Estimation of market value of enterprises: comparative approach]. Naukovyi visnyk NLTU Ukrainy Scientific Bulletin of UNFU of Ukraine, 15.4, 311-315 [in Ukrainian].

10. Black A., Wright P., Bachman I. In Search of Shareholder Value: Managing the Drivers of Performance. Financial Times Prentice Hall, $2001-366$ p. URL: https://books.google.com.ua/books/about/In_Search_of_Shareholder_Value.html?id=hoQiAQAAMA AJ\&redir_esc=y

11. Hendriksen E.A., Van Breda M.F. Accounting Theory URL: file:///C:/Users/user/Downloads/Accounting_Theory_Eldon_Hendriksen.pdf

12. De Wit B., Meyer R. Strategy Synthesis: Resolving Strategy Paradoxes To Create Competitive Advantage, 2010. URL: https://books.google.com.ua/books?hl=uk\&lr=\&id=A7sEYuPg7wC\&oi=fnd\&pg=PR5\&dq=De+Wit+B.,+Meyer+R.+Synthesis+of+strategies\&ots=AN1Y_C u-hu\&sig=aioN3-CqQrvQFX_T2oWcXIY9s5U\&redir_esc=y\#v=onepage\&q=De\%20Wit\%20B.\% 2C\%20Meyer\%20R.\%20Synthesis\%20of\%20strategies\&f=false

13. Ehrbar Al Using EVA To Measure Performance And Assess Strategy URL: https://www.emerald.com/insight/content/doi/10.1108/eb054637/full/html?skipTracking=true 
14. Mills R. W. The Dynamice of Shareholder Value. The Principles am! Practice of Strategic Value Analysis, Mars Business Associates, 1998. URL: https://downloadspace.com/download/book/Mills,Roger_W._The_Dynamics_Of_Shareholder_Value.pdf.html?aff.id $=11556 \& \mathrm{dp}=5 \mathrm{ebeb} 24 \mathrm{e} 0 \mathrm{a} 5 \mathrm{df} 4000108 \mathrm{~d} 8 \mathrm{c} 5$

15. Rappaport A. Creating Shareholder Value: A Guide For Managers And Investors, 1999 p. - 224. URL: https://books.google.com.ua/books?id=bc0PjplGR5gC\&printsec=frontcover\&hl= $\mathrm{uk} \&$ source $=\mathrm{gbs} \_\mathrm{ge} \_$summary_r$\&$ cad $=0 \# \mathrm{v}=$ onepage $\& \mathrm{q} \& \mathrm{f}=$ false

16. Bilichenko V. Research of Influence of Specialization Level of Permanent Repair Posts On Efficiency of Autoservice Enterprises Functioning / V. Bilichenko, S. Tsymbal // Bulletin of polytechnic institute of Iasi. - 2014. Volume LX (LXIV). Fasc. 2 - P. 45-58.

\section{Лimepamypa:}

1. Друкер П. Задачи менеджмента в XXI веке: /Пер. с англ. - М.: Изд. Дом «Вильямс», 2000. -272 c.

2. Железняк К. Л. Вибір стратегії розвитку автотранспортного підприємства як елемента фрагментарної галузі / К. Л. Железняк // Вісник Національного транспортного університету. В 2-х частинах. Ч. 2. - К. : НТУ, 2012. - Випуск 26. - С. 147-150. [Електронний pесурс]. - Режим доступу: http://irbis-nbuv.gov.ua/cgi-bin/irbis_nbuv/cgiirbis_64.exe?C21COM= $2 \& I 21 D B N=U J R N \& P 21 D B N=U J R N \& I M A G E \_F I L E \_D O W N L O A D=1 \& I m a g e$ file_name=PDF/Vn tu_2012_26\%282\%29_30.pdf

3. Замазій О.В. Формування ціннісно-орієнтованого управління промисловими підприємствами: автореф. дис. ... д-ра екон. наук: спец. 08.00.04 «Економіка та управління підприємствами (за видами економічної діяльності)» / О.В. Замазій. - Хмельницький : Хмел. нац. ун-т, 2015. - 41 с.

4. Коупленд, Т. Стоимость компаний: оценка и управление [Текст] / Т. Коупленд, Т. Коллер, Д. Муррин. - 2-е изд. - М. : ЗАО «Олимп-Бизнес», 2002. - 565 с.

5. Мендрул О.Г. Управління вартістю підприємств: теоретичні та практичні аспекти: автореф. дис. ... д-ра екон. наук: спец. 08.06.01 «Економіка, організація і управління підприємствами» / О.Г. Мендрул. - Київ : Київ. нац. екон. ун-т, 2003. - 34 с.

6. Островська Г. Й. Запровадження системи вартісно-орієнтованого управління вертикально-інтегрованих підприємств. //Галицький економічний вісник. - Тернопіль, 2007. №2. - C.38-51.

7. Плікус І.Й. Потенціал підприємства, його оцінка й трансформація: економічна та бухгалтерська інтерпретація / Плікус І.Й. // Фінанси України. - 2012. - № 4. -c.91-105.

8. Цимбал С.В. Обгрунтування стратегій розвитку підприємств автомобільного транспорту / С.В. Цимбал // LXX наукова конференція професорсько-викладацького складу, аспірантів, студентів та співробітників відокремлених структурних підрозділів Національного транспортного університету : тези доповідей. - Київ, 2014. - С. 302.

9. Яремко І.Й. Оцінка ринкової вартості підприємств: порівняльний підхід І.Й. Яремко // Науковий вісник НЛТУ України. Зб. наук.-техн. пр. - Львів, 2005. - С. 311-315

10. Black A., Wright P., Bachman I. In Search of Shareholder Value: Managing the Drivers of Performance. Financial Times Prentice Hall, 2001 - 366 p. URL: https://books.google.com.ua/ books/about/In_Search_of_Shareholder_Value.html?id=hoQiAQAAMAAJ\&redir_esc=y

11. Hendriksen E.A., Van Breda M.F. Accounting theory URL: file:///C:/Users/user/ Downloads/ Accounting_Theory_Eldon_Hendriksen.pdf

12. De Wit B., Meyer R. Strategy synthesis: Resolving strategy paradoxes to create competitive advantage, 2010. URL: https://books.google.com.ua/books?hl=uk\&lr=\&id=A7sEYuPg7wC\&oi=fnd\&pg=PR5\&dq=De+Wit+B.,+Meyer+R.+Synthesis+of+strategies\&ots=AN1Y_C u-hu\&sig=aioN3-CqQrvQFX_T2oWcXIY9s5U\&redir_esc=y\#v=onepage\&q=De\%20Wit\%20B.\% 2C\% 20Meyer\%20R.\%20Synthesis\%20of\%20strategies\&f=false

13. Ehrbar Al Using EVA to measure performance and assess strategy URL: https://www.emerald.com/insight/content/doi/10.1108/eb054637/full/html?skipTracking=true 
14. Mills R. W. The Dynamice of Shareholder Value. The Principles am! Practice of Strategic Value Analysis, Mars Business Associates, 1998. URL: https://downloadspace.com/download/book/Mills,Roger_W._-

_The_Dynamics_Of_Shareholder_Value.pdf.html?aff.id=11556\&dp=5ebeb24e0a5df4000108d8c5

15. Rappaport A. Creating Shareholder Value: A Guide For Managers And Investors, 1999 p. -224 .

URL: https://books.google.com.ua/books?id=bc0PjplGR5gC\&printsec=frontcover\&hl=uk\&source=g bs_ge_summary_r\&cad $=0 \# v=$ onepage $\& \mathrm{q} \& \mathrm{f}=$ false

16. Bilichenko V. Research of influence of specialization level of permanent repair posts on efficiency of autoservice enterprises functioning / V. Bilichenko, S. Tsymbal // Bulletin of polytechnic institute of Iasi. - 2014. Tomul LX (LXIV). Fasc. 2 - P. 45-58. 